\title{
ASSESSMENT OF ANTI-INFLAMMATORY ACTIVITY OF ETHANOLIC EXTRACT OF ASAM KANDIS (GARCINIA XANTHOCHYMUS HOOK. F. EX T. ANDERSON) FRUIT
}

\author{
HANAFIS SASTRA WINATA ${ }^{1 *}$, ROSIDAH ROSIDAH $^{1}$, PANAL SITORUS $^{2}$ \\ ${ }^{1}$ Department of Pharmacology, Faculty of Pharmacy, University of Sumatera Utara, Medan, Indonesia. ${ }^{2}$ Department of Biological Pharmacy, \\ Faculty of Pharmacy, University of Sumatera Utara, Medan, Indonesia. Email: nafis.sastrawinata@gmail.com
}

Received: 10 November 2017, Revised and Accepted: 15 December 2017

\section{ABSTRACT}

Objective: The objective of this study was to evaluate the anti-inflammatory activity in acute and subacute models of inflammation from ethanolic fruit extract of Asam kandis (Garcinia xanthochymus Hook. f. ex T. Anderson) in animal (rats) models.

Methods: Pleliminary phytochemical screening was carried out by using standard procedures.. Assessment of acute and subacute models of inflammation was using carrageenan-induced paw edema method and cotton pellet granuloma method using three dosage treatments; $200 \mathrm{mg} / \mathrm{kg}$ BW, $400 \mathrm{mg} / \mathrm{kg} \mathrm{BW}$, and $800 \mathrm{mg} / \mathrm{kg}$ BW along with a negative control group (0.5\% Na CMC) and positive control (Na diclofenac $2.25 \mathrm{mg} / \mathrm{kg} \mathrm{BW}$ ). The inhibition period was observed at 30, 60, 90, 120, 150, and 180 min time intervals.

Result: The phytochemical screening showed that the ethanolic fruit extract from Asam kandis contain contains flavonoids, glycosides, steroids, and triterpenoids. The anti-inflammatory result showed that the strongest inhibition produced by ethanolic fruit extract of Asam kandis occurred on the dosage of $800 \mathrm{mg} / \mathrm{kg} \mathrm{BW}$ compared to the other doses (200 and $400 \mathrm{mg} / \mathrm{kg} \mathrm{BW}$ ) throughout the observation period.

Conclusion: This finding indicated that ethanolic fruit extract of Asam kandis (G. xanthochymus Hook. f. ex T. Anderson) might become an interesting candidate for treatment of inflammation.

Keywords: Asam kandis, Anti-inflammatory, Carrageenan, Paw edema, Cotton pellet.

(c) 2018 The Authors. Published by Innovare Academic Sciences Pvt Ltd. This is an open access article under the CC BY license (http://creativecommons. org/licenses/by/4. 0/) DOI: http://dx.doi.org/10.22159/ajpcr.2018.v11i4.23578

\section{INTRODUCTION}

Inflammation is the defensive response of the body which is nonspecific toward the tissue injury and infection. Pain and inflammation are two states associated with numerous diseased conditions [1]. There are many conditions that could trigger the inflammation such as pathogens, chemical irritation, extreme temperature, distortion or disturbances of cells, and abrasions [2-4]. There are five characteristics of inflammation such as redness, swelling, the rise of temperature, pain, and loss of function [5].

Non-steroidal anti-inflammatory drug (NSAID) is one of the most common medications for inflammation, but unexpected bronchus, gastric mucosa, cardiac, and kidney-related side effects have been reported [6]. The utilization of natural sources to search for new pharmacologically active agents has led to the discovery of many clinically beneficial drugs that contributes to a key role in the treatment of human disease [7]. Therefore, many researchers are interested in drugs from the natural sources such as plants and herbs origin due to their wide range of pharmacological activities, including antiinflammatory potential with minimum side effects [8].

Garcinia xanthochymus Hook. f. ex T. Anderson, also called as Asam kandis, belongs to the Clusiaceae family. Garcinia species are common in Southeast Asia. This species is rich of the phytochemicals compound that includes xanthone, flavonoids, and phenolic acids. Due to its rich pharmaceutical values, mostly the Garcinia species have been to treat many diseases such as antifungal, antioxidant, antiprotozoal, and antiimmunosuppressive [9]. In vitro investigation reported that the ethanolic fruit extract of G. xanthochymus has a good antioxidant effect (half maximal inhibitory concentration [ $\left[\mathrm{IC}_{50}\right]$ : $22 \mu \mathrm{g} / \mathrm{mL}$ ] [10]. Therefore, from the previous investigation, it can be concluded that $G$. xanthochymus has a good antioxidant properties. In this regard, it makes great sense to evaluate the anti-inflammatory activity of Asam kandis (G. xanthochymus Hook. f. ex T. Anderson) fruit ethanolic extract using carrageenan-induced paw edema method and cotton pellet method.

\section{METHODS}

Identification and authentication of plant materials

Asam kandis (G. xanthochymus Hook. f. ex T. Anderson) fruits were obtained from region of Lubuk Minturun, Padang, West Sumatera, Indonesia. Fresh fruits were dried and then grounded to obtain a finely divided powder.

\section{Plant extraction preparation and phytochemical screening}

The powder of Asam kandis (G. xanthochymus Hook. f. ex T. Anderson) fruits was extracted using a triple maceration process with ethanol organic solvent. $900 \mathrm{~g}$ of powdered Asam kandis fruits is macerated in advance with the ethanol solvent for 5 days, then filtered, do it continuously until the filtrate obtained is clear and colorless [11]. Phytochemical screening carried out on Asam kandis fruits ethanolic extract includes examining the chemical secondary metabolites of alkaloids, flavonoids, glycosides, tannins, triterpenoids, and steroids. The preliminary phytochemical screening was using widely used methods [12-14].

\section{Preparation of animals}

Healthy adult male Wistar rats (150-200 g body weight) from animal house of Faculty of Pharmacy, University of Sumatera Utara, were used for the study. Rats were housed in a polycarbonate cages in a room with $12 \mathrm{~h}$ day-night circle. They were fed on a standard pellet diet and water ad libitum. The study was approved by Animal Research Ethics Committees (AREC) of University of Sumatera Utara (AREC No: 120/ KEPH-FMIPA/2017) and the experiments were conducted according to the ethical norms and AREC guidelines. 
Anti-inflammatory activity

Carrageenan-induced paw edema

Healthy adult male Wistar rats were divided into five groups of six rats each. Edema was induced by injecting $0.05 \mathrm{~mL}$ of $1 \%$ carrageenan suspension into the subplantar region of the right hind paw of the rats. Control group rats received $0.5 \%(\mathrm{w} / \mathrm{v}) \mathrm{Na}$ CMC and the reference group of rats received $2.25 \mathrm{mg} / \mathrm{kg} \mathrm{BW}$ sodium diclofenac, orally. The test groups of rats were treated orally with 200,400 , and $800 \mathrm{mg} / \mathrm{kg}$ BW ethanolic extract of Asam kandis fruits 40 min before carrageenan injection. The paw volume was measured by plethysmometer before carrageenan injection $\left(\mathrm{V}_{0}\right)$ and 30, 60, 90, 120, 150, and 180 min after $\left(V_{\mathrm{t}}\right)$. The inflammation was calculated as the increase in volume $(\mathrm{mL})$ of the paw after treatment subtracted of basal volume. Results were expressed as percentage of inhibition of edema, calculated according to the formula $[15,16]$ :

$\begin{aligned} & \text { Percentage } \\ & \text { inhibition }(\%)\end{aligned}=\frac{\begin{array}{l}\text { Mean paw inflammation of control- } \\ \text { Mean paw inflammation of test }\end{array}}{\text { inflammation of control }} \times 100 \%$

\section{Cotton pellet granuloma method}

Wistar rats were divided into five groups of six rats each. Adsorbent cotton was made into pellets weighing $20 \pm 1 \mathrm{mg}$. The pellets were sterilized in a hot air oven at $120^{\circ} \mathrm{C}$ for $2 \mathrm{~h}$. The abdomen was shaved cleanly, swabbed with $70 \%$ ethanol, and the sterilized cotton pellet was implanted subcutaneously under light ether anesthesia. Test drugs were administered once daily throughout the experimental period of 7 days. On the $8^{\text {th }}$ day after implantation, rats were anesthetized and the pellets were dissected and dried at $60^{\circ} \mathrm{C}$ for $6 \mathrm{~h}$, weighed after cooling. The mean weight of the cotton pellets of the control group as well as of the test groups was calculated. The transudative weight and percent granuloma inhibition of the test compound were calculated [17]

\section{Statistical analysis}

The significant difference of data between different groups was compared by ANOVA followed by Duncan's test.

\section{RESULTS AND DISCUSSION}

This study investigated the anti-inflammatory activity of Asam kandis (G. xanthochymus Hook. f. ex T. Anderson) fruits ethanolic extract. The phytochemical screening of ethanolic extract of Asam kandis fruits revealed the presence of flavonoids, glycosides, steroids, and triterpenoids (Table 1). These results are related to previous research [18] that shown the presence of flavonoids, glycosides, steroids, and triterpenoids.

To evaluate the extract effect on anti-inflammatory activity, the ethanolic extract of Asam kandis fruits was tested using carrageenan-induced paw edema and cotton pellet granuloma method. In carrageenan-induced paw edema method, the paw volumes and percentage of inhibition of the control, standard, and test groups are shown in Figs. 1 and 2. The ethanolic fruit extract of Asam kandis showed anti-inflammatory activity compared to Na diclofenac. A dose of $800 \mathrm{mg} / \mathrm{kg}$ BW elicited a greater percent of inhibition of inflammatory after 60-180 min. These results showed that the ethanolic extract of Asam kandis fruit (dose $800 \mathrm{mg} / \mathrm{kg} \mathrm{BW}$ ) has the most potent anti-inflammatory activity.

The cotton pellet granuloma method has been widely used to access the subacute inflammation. The results are shown in Fig. 3. As shown in Fig. 3 , all the test groups have the inhibitory activity, but the best doses are 400 and $800 \mathrm{mg} / \mathrm{kg} \mathrm{BW}$. It can be shown by the percentage of inhibition for $400 \mathrm{mg} / \mathrm{kg} \mathrm{BW}$ is $58.10 \%$ and $35.89 \%$ for $800 \mathrm{mg} / \mathrm{kg} \mathrm{BW}$. These results suggest that the ethanolic extracts exhibit antitransudative effect.

Drugs from plant sources have been used for the treatment of various diseases since ancient times. Herbal drugs are inexpensive and effective with fewer side effects [19]. Nowadays, the use of herbal drugs to cure inflammation and pain is gaining popularity due to their effectiveness,
Table 1: Phytochemical screening result of ethanolic extract from Asam kandis fruits

\begin{tabular}{lll}
\hline No & Screening & Result \\
\hline 1 & Alkaloids & Negative \\
2 & Flavonoids & Positive \\
3 & Glycosides & Positive \\
4 & Tannins & Negative \\
5 & Saponins & Negative \\
6 & Triterpenoid/steroids & Positive \\
\hline
\end{tabular}

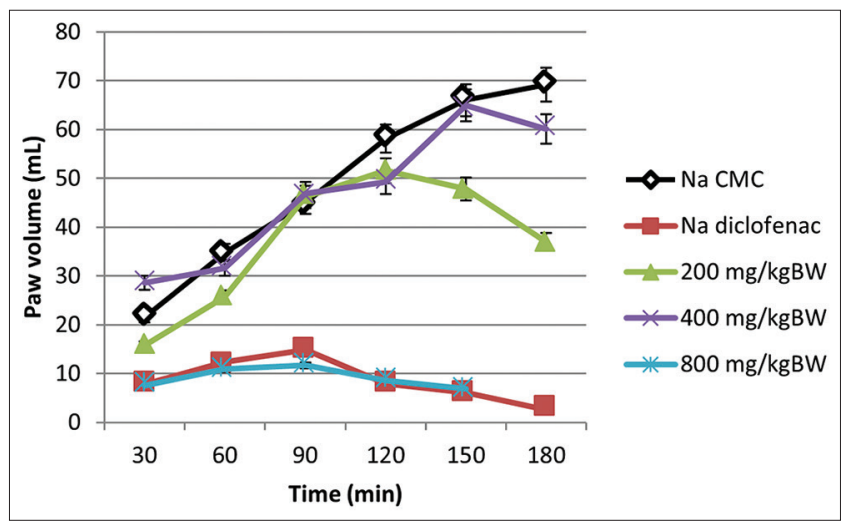

Fig. 1: Effect of various doses of Asam kandis fruit ethanolic extract in carrageenan-induced paw edema in rats (change in mean paw volume)

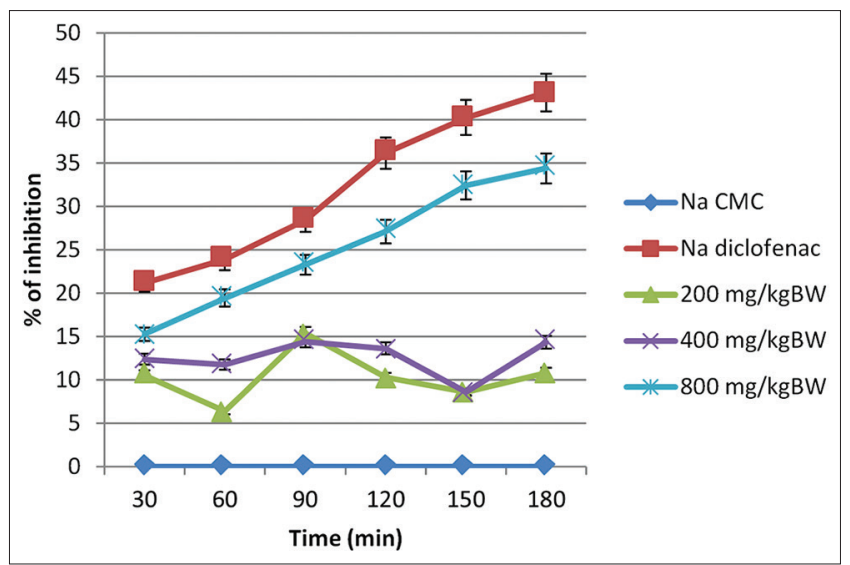

Fig. 2: Effect of various doses of Asam kandis fruit ethanolic extract in carrageenan-induced paw edema in rats $(\%$ of inhibition)

fewer side effects, low cost, and availability. NSAIDs act by inhibiting cyclooxygenase and the production of prostaglandins. Diclofenac offers relief from inflammation by suppressing the production of prostaglandins and bradykinin. The presence of flavonoids has been reported in Garcinia species, and flavonoids are known to inhibit prostaglandin synthetase. Previous studies have shown similar relationships between flavonoids and anti-inflammatory effects [20-29] Therefore, it is possible that the anti-inflammatory action of Asam kandis fruit extract may be related to the inhibition of prostaglandin synthesis. The phytochemical profile of Asam kandis fruit extract may be explored further to identify the active constituents responsible for its anti-inflammatory activity.

\section{CONCLUSIONS}

The ethanolic extract of Asam kandis fruit (G. xanthochymus Hook. f. ex T. Anderson) ethanoic extract at dose of $800 \mathrm{mg} / \mathrm{kg} \mathrm{BW}$ had the most 


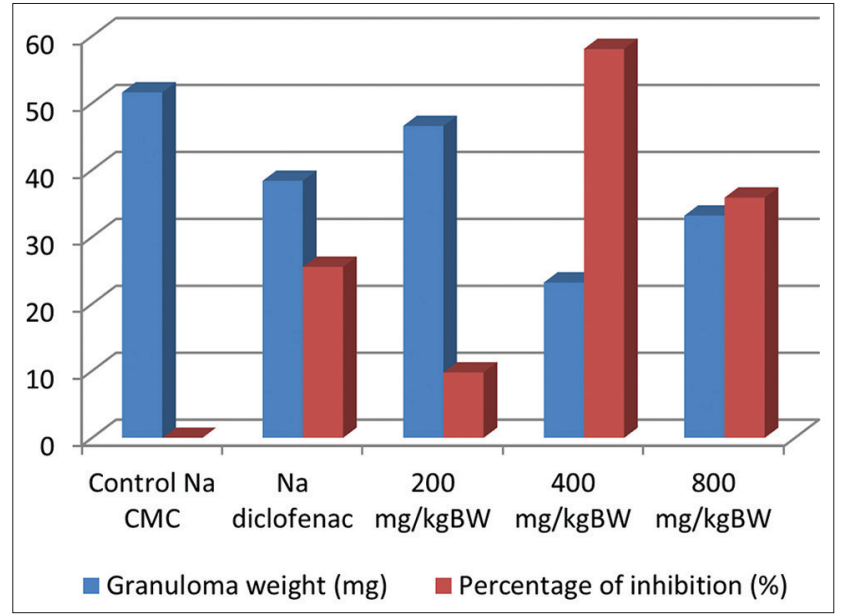

Fig. 3: Effect of various doses of Asam kandis fruit ethanolic extract in cotton pellet granuloma method

potent anti-inflammatory activity throughout the observation period. These studies can be concluded that Asam kandis fruit (G. xanthochymus Hook. f. ex T. Anderson) has the potential to be developed as an antiinflammatory agent.

\section{ACKNOWLEDGMENTS}

I express my thanks to Iksen, B. Pharm., M.Sc. (USU), for his never ending guidance and suggestions throughout the preparation of this research and article.

\section{AUTHORS CONTRIBUTIONS}

All the author have contributed equally.

\section{CONFLICT OF INTERESTS}

Declared none.

\section{REFERENCES}

1. Bhatia DK, Paliwal SK. Membrane stabilzation, inhibition of histamine and prostaglandin synthesis mediated anti-inflammatory response of some indigenous plants. Int J Pharm 2014;1:660-7.

2. Lee CJ, Chen LG, Liang WL, Wang CC. Antiinflammatory effects of Punica granatum Linne in vitro and in vivo. Food Chem 2010;118:315-22.

3. Rim HK, Yun $\mathrm{CH}$, Shin JS, Cho YW, Jang DS, Ryu JH, et al. 5,6,7-trimethoxyflavone suppresses pro-inflammatory mediators in lipopoly-saccharide-induced RAW 264.7macrophages and protects mice from lethal endotoxinshock. Food Chem Toxico 2013;62:847-55.

4. Sutrisno E, Adnyana K, Sukandar EY, Fidrianny I, Aligita W. Antiinflammaotry study of Anredera cordifolia leaves and Centella asiatica herbs and its combination using human red blood cell-membrane stabilization method. Asian J Pharm Clin Res 2016;9:78-80.

5. Joyce KL, Hayes ER. Farmakologi Pendekatan Proses Keperawatan. Jakarta: Penerbit Buku Kedokteran ECG; 1996.

6. Wallace JL, Vong L. NSAID-induced gastrointestinal damage and the design of GI-sparing NSAIDs. Curr Opin Investig Drugs 2008;9:1151-6.

7. Cragg GM, Newman, DJ. Natural products: A continuing source of novel drug leads. Biochim Biophys Acta 2013;1830:3670-95.

8. Ibrahim B, Sowemimo A, van Rooyen A, Van de Venter M. Anti-inflammatory, analgesic and antioxidant activities of Cyathula prostrata (Linn.) Blume (Amaranthaceae). J Ethnopharmacol 2012;141:282-9.

9. Kumar S, Sharma S, Chattopadhyay SK. The potential health benefit of polyisoprenylated benzophenones from Garcinia and related genera: Ethnobotanical and therapeutic importance. Fitoterapia 2013;89:86-125

10. Winata HS. Antioxidant and Anti-Inflammatory Activity of Asam Kandis Fruit (Garcinia xanthocymus) Ethanolum Extract Against White Male Rats. Thesis Faculty of Pharmacy, University of Sumatera Utara; 2017. p. 1-104.

11. Ditjen PO. Farmakope Indonesia. Depkes RI 1995;4:896-8.

12. Depkes RI. Materia Medika. Ditjen POM 1995;6:297-307.

13. Farnsworth NR. Biologycal and phytochemical screening of plants. J Pharm Sci 1996;55:225-76.

14. Harbone JB. Metode Fitokimia. ITB 1987;2:6, 49

15. Winter CA, Risley EA, Nuss GW. Carrageenin induced oedema in hindpaws of the rats as an assay of anti-inflammatory drugs. Proc Soc ExpBiol Med 1962;111:544-7

16. Yu D, Yuan Y, Jiang L, Tai Y, Yang X, Hu F, et al. Anti-inflammatory effects of essential oil in Echinacea purpurea L. Pak. J Pharm Sci 2013;26:403-8.

17. Swingle KF, Shiderman FE. Phases of the inflammatory response to subcutaneous implantation of a cotton pellet and their modificationby certain anti-inflammatory agents. J Pharm Exp Ther 1972;183:226-34.

18. Ramadhani IM, Lestari F, Yuniarni U. Pengaruh Ekstrak Etanol Kulit Buah Asam Kandis (Garcinia parvifolia) Seabgai Hepatoprotektro Pada Tikus Wistar Jantan Yang Diiduksi Isoniazid dan Rifampisin. Prosiding Penelitian SPeSIA; 2015

19. Haro G, Sinaga SM, Iksen I, Nerdy N, Theerachetmongkol S. Protective effect of chives leaves (Allioum schoenoprasum, L.) infusion against ethylene glycol and ammonium chloride induced nephrolithiasis in rats. J Appl Pharm Sci 2017;7:222-5.

20. Shin JS, Baek SR, Sohn SI, Cho YW, Lee KT. Anti-inflammatory effect of pelubiprofen acid, mediated by dual supression of COX activity and LPS-induced inflammatory gene expression via NF-kB inactivation. J Cell Biochem 2011;112:3594-603.

21. Yun KJ, Koh DJ, Kim SH, Park SJ, Ru SJ, Kim DG, et al. Anti-inflammatory effects of sinapic acid through the suppression od inducible nitric acid oxide synthase, cycooxygase-2 and proinflmammatory cytokinesis expressions via nuclear factor-kappaB inactivation. J Agric Food Chem 2008;56:10265-72.

22. Martini ND, Katerere DR, Eloff JN. Biological activity of five antibacterial flavonoids from Combretum erythrophyllum (Combretaaceae). J Ethnopharmacol 2004;93:207-12

23. Nguyen VL, Truong CT, Nguyen BC, Vo TV, Dao TT, Nguyen VD, et al. Anti-inflammatory and wound healing activities of calophyllolide isolated from Calophyllum inophyllum Linn. Plos One 2017;12:1-16.

24. Toker G, Kupelo E, Memisoolu M, Yesilada E. Flavonoids with antinociceptive and antiinflammatory activities from the leaves of Tilia argentea (Silver Linden). J Ethnopharmacol 2004:95:393-7.

25. Mehta V, Sharma A, Kailkhura P, Malairaman U. Antioxidant, anti0inflammatory and antidiabetic activity of hydroalcoholic extract of Ocimum sanctum: An in vitro and in dilico study. Asian J Pharm Clin Res 2016;9:44-9.

26. Vinueza D, Lopez E, Acosta K, Abdo S. Assessment of antiinflammaotry activity and cytotoxicity of freeze dried hydroalcoholic extract of Bidens andicola on isolated neutrophils. Asian J Pharm Clin Res 2017;10:160-3.

27. Ullah AH, Akter L, Zaman S, Juhara F, Tareq SM, Bhattacharjee R, et al. Anti-inflmammatory and analgesic activities of methanolic seed extract of Sterculia villosa Roxb. Asian J Pharm Clin Res 2015;8:247-51.

28. Laaboudi W, Ghanam J, Aissam H, Merzouki M, Benlemlih M. Antiinflammatory and analgesic activities of olive tree extract. Int J Pharm Pharm Sci 2016:8:414-9.

29. Shaikh S, Joshi YM, Kadam V. Comparative study of anti-inflammatory activity if aqueous and methanolic extracts of Hibiscus cannabinus leaf (Malvaceae). Int J Pharm Pharm Sci 2016;8:64-8. 